Columbia Law School

Scholarship Archive

\title{
Trade, Social Preferences, and Regulatory Cooperation: The New WTO-Think
}

Thomas J. Bollyky

Council on Foreign Relations, tbollyky@cfr.org

Petros C. Mavroidis

Columbia Law School, petros.mavroidis@unine.ch

Follow this and additional works at: https://scholarship.law.columbia.edu/faculty_scholarship

Part of the International Trade Law Commons

\section{Recommended Citation}

Thomas J. Bollyky \& Petros C. Mavroidis, Trade, Social Preferences, and Regulatory Cooperation: The New WTO-Think, Robert Schuman Centre for Advanced Studies, Global Governance Programme Working PAPER No. RSCAS 2016/45; Columbia LAW \& ECONOMICS WoRkINg PAPER No. 546 (2016).

Available at: https://scholarship.law.columbia.edu/faculty_scholarship/2363

This Working Paper is brought to you for free and open access by the Faculty Publications at Scholarship Archive. It has been accepted for inclusion in Faculty Scholarship by an authorized administrator of Scholarship Archive. For more information, please contact scholarshiparchive@law.columbia.edu. 

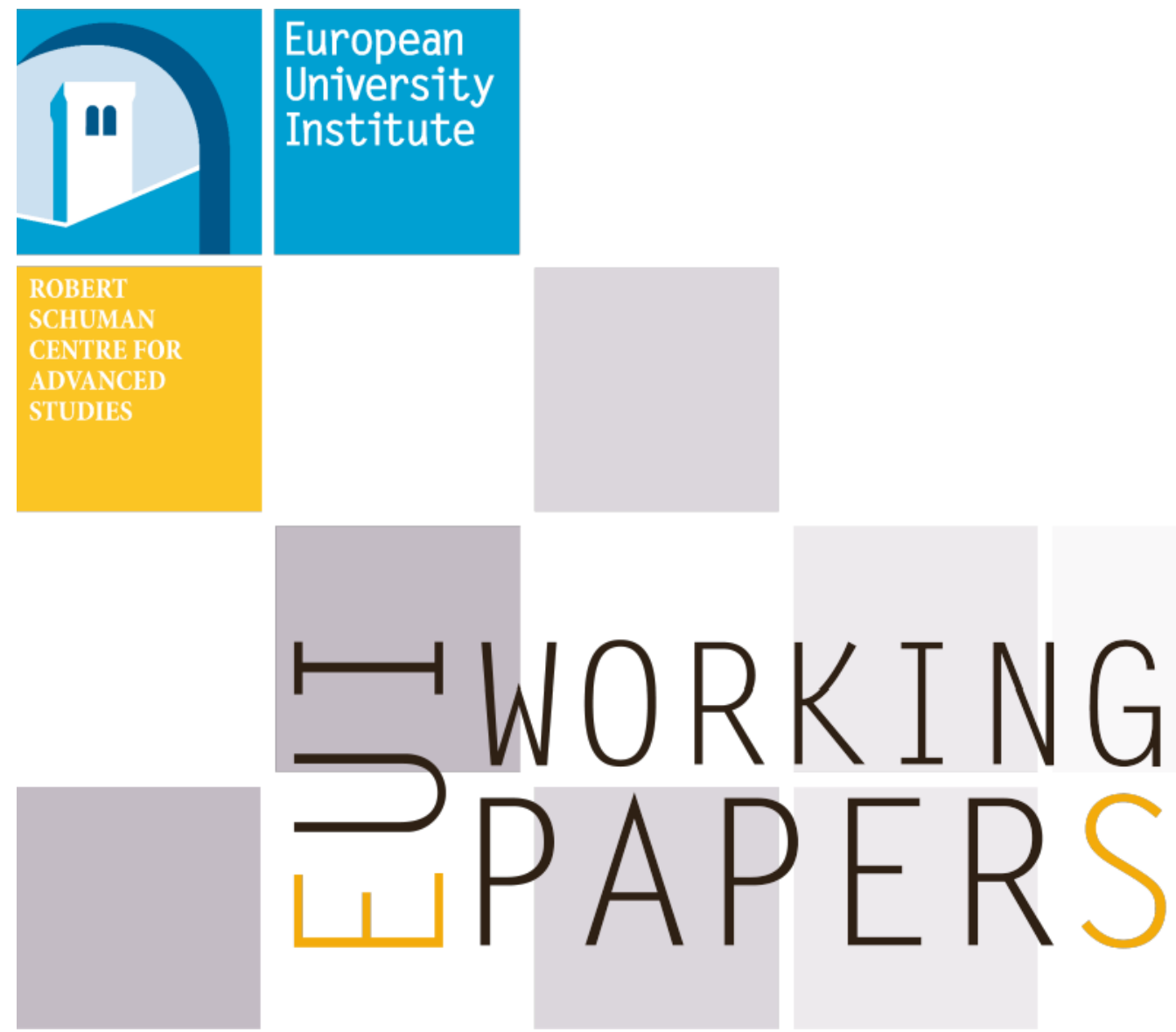

RSCAS 2016/47

Robert Schuman Centre for Advanced Studies Global Governance Programme-231

Trade, Social Preferences and Regulatory Cooperation The New WTO-Think

Thomas J. Bollyky and Petros C. Mavroidis 
European University Institute

Robert Schuman Centre for Advanced Studies

Global Governance Programme

Trade, Social Preferences and Regulatory Cooperation The New WTO-Think

Thomas J. Bollyky and Petros C. Mavroidis

EUI Working Paper RSCAS 2016/47 
This text may be downloaded only for personal research purposes. Additional reproduction for other purposes, whether in hard copies or electronically, requires the consent of the author(s), editor(s). If cited or quoted, reference should be made to the full name of the author(s), editor(s), the title, the working paper, or other series, the year and the publisher.

ISSN 1028-3625

(C) Thomas J. Bollyky and Petros C. Mavroidis, 2016

Printed in Italy, September 2016

European University Institute

Badia Fiesolana

I - 50014 San Domenico di Fiesole (FI)

Italy

www.eui.eu/RSCAS/Publications/

www.eui.eu

cadmus.eui.eu 


\section{Robert Schuman Centre for Advanced Studies}

The Robert Schuman Centre for Advanced Studies (RSCAS), created in 1992 and directed by Professor Brigid Laffan, aims to develop inter-disciplinary and comparative research on the major issues facing the process of European integration, European societies and Europe's place in $21^{\text {st }}$ century global politics.

The Centre is home to a large post-doctoral programme and hosts major research programmes, projects and data sets, in addition to a range of working groups and ad hoc initiatives. The research agenda is organised around a set of core themes and is continuously evolving, reflecting the changing agenda of European integration, the expanding membership of the European Union, developments in Europe's neighbourhood and the wider world.

Details of the research of the Centre can be found on: http://www.eui.eu/RSCAS/Research/

Research publications take the form of Working Papers, Policy Papers, and e-books. Most of these are also available on the RSCAS website:

http://www.eui.eu/RSCAS/Publications/

The EUI and the RSCAS are not responsible for the opinions expressed by the author(s).

\section{The Global Governance Programme at the EUI}

The Global Governance Programme is one of the flagship programmes of the Robert Schuman Centre for Advanced Studies at the European University Institute (EUI). It aims to: build a community of outstanding professors and scholars, produce high quality research and, engage with the world of practice through policy dialogue. At the Global Governance Programme, established and early career scholars research, write on and discuss, within and beyond academia, issues of global governance, focussing on four broad and interdisciplinary areas: European, Transnational and Global Governance; Global Economics; Europe in the World; and Cultural Pluralism.

The Programme also aims to contribute to the fostering of present and future generations of policy and decision makers through its unique executive training programme, the Academy of Global Governance, where theory and "real world" experience meet. At the Academy, executives, policy makers, diplomats, officials, private sector professionals and academics, have the opportunity to meet, share views and debate with leading academics, top-level officials, heads of international organisations and senior executives, on topical issues relating to governance.

For more information: http://globalgovernanceprogramme.eui.eu 



\begin{abstract}
This paper advocates changes in the corporate governance of the World Trade Organization (WTO) to reflect the decline in tariffs and other border restraints to commerce and the emerging challenges of advancing freer trade and better regulation cooperation in a world economy dominated by global value chains. Together, these changes form an integration strategy that we refer to as the new WTO Think. This strategy remains rooted in the original rationale of the General Agreement on Trade and Tariffs (GATT) of reducing the negative externalities of unilateral action and solving important international coordination challenges, but is more inclusive of regulators and non-state actors and more flexible and positive in its means. In particular, we advocate that the WTO should embrace the confluence of shared social preferences and trade, where it exists, as a motivation for advancing international regulatory cooperation. The WTO should also multilateralize the important regulatory cooperation occurring in smaller clubs of like-minded countries and better facilitate the use of plurilateral agreements where consensus across all WTO members is not yet possible.
\end{abstract}

\title{
Keywords
}

WTO; Reciprocity; MFN; Regulatory Cooperation

JEL Classification: K40 



\section{Introductory Remarks*}

Understanding that there are important gains to be had from international cooperation does not itself ensure that cooperative behavior will emerge. This was one of the lessons of trade in the interwar period, when governments were unable through proclamations and solo measures alone to arrest the cycle of retaliation that followed the U.S. Smoot-Hawley Tariff Act of 1930, resulting in tariff levels of nearly 50 percent among the major powers. That experience led to the negotiation of the General Agreement on Trade and Tariffs (GATT). Its rationale-or GATT-think-was that reciprocal liberalization would curb unilateral protection and the negative externalities that result from uncoordinated and non-transparent actions in a trading system with many partners (Bagwell and Staiger, 2002).

GATT-think succeeded beyond any reasonable expectation. This rules-based global trading system helped reduce tariffs and other border restraints and institutionalized global economic integration as a force for peace and prosperity. The average level of tariffs for OECD member countries fell to 3 percent; the average applied tariff in emerging economies like China and India is less than 10 percent (World Trade Organization, 2014). Membership in the GATT and its successor institution, the World Trade Organization (WTO), grew from 23 countries in 1947 to 164 nations today. ${ }^{1}$ Trade liberalization and increased global economic integration, in the mind of some experts, have contributed to other important gains as well: fewer wars and improved living standards in most nations of the world. ${ }^{2}$

As a result of GATT's success and drastically reduced tariffs, the way the world trades has changed in recent decades. The relative importance of regulations and standards as determinants of market access grew. That importance has only increased with the subsequent disciplining of other border restraints on trade through the WTO Agreements on Customs Valuation, Import Licensing, and, more recently, on Trade Facilitation. At the same time, greater global economic integration, democratization, rising living standards, and increased awareness of risks have increased the demand for more regulations and rules, as means of preserving and advancing social preferences on matters such as worker, environmental, and public health protection. ${ }^{3}$ More trade occurs now via global value chains (GVCs), which rely on consistent, efficient, and adequate regulatory oversight to function. ${ }^{4}$ The challenge of organizing consistent regulations is likely to grow with more products integrating valueadded services and cross-border data flows - areas in which the WTO trade disciplines are few.

The global trading system has not adapted to these changes. The WTO still hews to the negative integration strategy of the GATT on regulations and social preferences, geared toward preventing domestic policies from being used to erode tariff concessions. This approach helped reduce explicitly protectionist regulations, but has done little to improve the international regulatory cooperation that is increasingly critical to freer trade. In the absence of that progress, countries are turning to bilateral and regional trade agreements to deepen their integration on regulatory matters. Businesses and consumers are relying on private or non-profit organization standards and third-party certifications to enforce

\footnotetext{
For helpful discussions we would like to thank Kyle Bagwell, Henrik Horn, and Damien J. Neven. For research assistance, we thank Birdy Assefa and Matt Cohen.

1 “Accessions: Afghanistan to Become 164 ${ }^{\text {th }}$ WTO Member on 29 July 2016.” World Trade Organization, 29 June 2016.

2 Pinker (2011); Radelet (2015). Irwin et al. (2008). Cordell Hull, one of the architects of the GATT trading regime, was awarded the Nobel Prize for Peace for his contributions.

3 In this piece, we define social preferences as fundamental interests that are not necessarily limited to a particular state. That definition distinguishes social preferences, which may transcend national boundaries, from the domestic policies of nation states or the transient negotiating demands, foreign policy goals, or bargaining positions that those states use to conduct foreign affairs. This definition draws loosely from the notion of preferences in Moravcsik (1997).

4 Michael Porter popularized the value chain concept. His underlying notion was that a firm should focus on the stages and support functions in which that firm has a comparative advantage and outsource the rest (Porter, 1985).
} 
social preferences and quality requirements. The resulting cacophony of rules and private standards has increased compliance costs and undermined effective international regulatory oversight. Popular support for liberalization of trade is already diminishing in many countries; that decline may accelerate without efforts to ensure that more trade also means better public health and a more protected environment.

We should not need to relearn the lesson of the inter-war era that unnecessary harm can result from uncoordinated and non-transparent actions in a global trading system with many partners and no strong institutional support. More international cooperation would improve the consistency, efficiency, and adequacy of regulations, which is in the mutual interest of trade officials and regulators alike. This, however, does not mean more international regulatory cooperation will spontaneously occur.

Here, WTO has an important role to play. Regulatory agencies are domestic in their orientation and their international cooperation initiatives often lack the funding, high-level political support, and urgency that trade negotiations can provide. Bilateral and regional preferential trade agreements (PTAs) are advancing international regulatory cooperation beyond disciplines on nondiscrimination, but most exclude many of the lower-income nations engaged in GVCs. While developing countries have been able to reducing tariffs unilaterally to better compete in a world economy dominated by GVCs, the options for doing so in the regulatory context are limited. Pursuing international regulatory cooperation on a multilateral basis and within WTO avoids the need for multiple, parallel cooperation initiatives between the various sets of regulatory agency counterparts and trading partners involved in a GVC. It also takes advantage of the emphasis on rules-based, nondiscriminatory trade and process for regulatory convergence, albeit rudimentary, that already exist at the WTO.

To advance this cause, we need a new WTO-think, a strategy that is better suited to the present challenges of the global economy. This strategy remains rooted in the original rationale of the GATT of reducing the negative externalities of unilateral action and solving important international coordination challenges, but is more inclusive of regulators and non-state actors and more flexible and positive in its means. To do this, we advocate that the WTO should embrace the confluence of shared social preferences and trade, where it exists, as a motivation for advancing international regulatory cooperation. We also recommend that the WTO rethink its corporate governance along the lines of variable geometry, an idea outlined in Lawrence (2006) and Hoekman and Mavroidis (2015). Building on that work, we develop a workable mechanism for multilateralizing the progress being made on regulatory cooperation initiatives at the sub-WTO level. We also propose changes to WTO rules to facilitate the use of plurilateral agreements where consensus across members is not yet possible.

\section{GATT-Think}

Why do we need multilateral trade agreements? There are sizable benefits to eliminating protectionist policies, irrespective of whether other nations do the same. For this reason, some economists have characterized the multilateral trade system as enlightened mercantilism, a framework of rules and reciprocal liberalization that create political tradeoffs and domestic lobbies for making the tariff reductions that governments should already do for economic reasons (Krugman, 1991, 1997). ${ }^{5}$

We characterize the purpose of the GATT-GATT-think - differently. There are good arguments why some nations might want to protect. ${ }^{6}$ Proponents of the terms of trade theory would suggest that those who have the bargaining power to do so can profit from imposing tariffs that reduce the world

\footnotetext{
In other words, the prospect of tariff reductions in other nations helps generate enough support from export-minded interests to overcome the opposition of domestic interests opposed to lower tariffs and the possibility of increased imports.

6 Regan (2006) (including revenue-raising, socially valued redistribution, and correcting externalities, including those affecting infant industries, as among the 'perfectly proper' goals for protection).
} 
price to their advantage. ${ }^{7}$ Economic history on the other hand, is full of examples of tariff impositions for various reasons. ${ }^{8}$ Absent international agreement, (some) nations might have little incentive to eliminate protection. Further, there are virtues of international agreements beyond the creation of political tradeoffs and domestic lobbies for lower tariffs. Rules-based, reciprocal liberalization provides predictability, prevents backsliding, and creates forward momentum for deeper economic integration. By drawing more countries into a rules based system, multilateral trade agreements create static and dynamic efficiencies of scale.

The genius of the GATT lies with its approach to disciplining protection. Instead of seeking to define and prohibit protectionism in all its potential forms, the GATT channels protectionism from outright import quotas (which it outlaws per se) toward a less pernicious and more transparent form of protection (tariffs) and making it negotiable. ${ }^{9}$ Once bound, tariff levels may only decrease. The requirement for nondiscriminatory application of domestic ('behind the border') policies was an insurance policy intended to prevent avoid the use of regulatory measures to replace, and thereby erode, tariff concessions. Having the outcome of tariff negotiation extend to all GATT members on a non-discriminatory basis created a powerful incentive for other nations to participate in the system. Enforceable dispute resolution kept them following the rules. So if negotiations persisted and succeeded, protection would gradually become extinct. Or, at least, this was the idea. ${ }^{10}$

The GATT is concerned primarily with disciplining the unilateral imposition of border instruments, policies that affect only imports. Accordingly, the GATT requires import and export quotas to be abolished with immediate effect, capping tariffs (to restrain volatility, and the resulting uncertainty), and applying tariffs, in principle, in a nondiscriminatory and transparent way. ${ }^{11}$ The negotiators were determined to avoid a repeat of the escalating tariffs and trade wars that had characterized the interwar period. Tariffs levels had receded some by the time that GATT negotiations began, but the average tariff was still 22 percent in 1947 (Bown \& Irwin, 2016).

The intent of the GATT framers was to reduce negative externalities that may result from uncoordinated and non-transparent use of protectionist measures in a trading system with many partners. The limited rules on regulations and other nontariff measures that exist in the GATT play a supporting role in that effort. The framers were well aware of the risk of policy substitution in this arrangement, for some of the brightest minds of that generation participated in the negotiation of the GATT. ${ }^{12}$ Thus, commitments on domestic policies were necessary; otherwise the value of tariff bindings would be easily eroded. What does it mean to bind customs duties, if domestic taxes (to consumers) and subsidies (to producers) are left unconstrained? The discipline on domestic policies however, was softer. Those adhering to the GATT had to promise to place domestic and imported competing goods at equal footing. Nondiscrimination was thought to be an adequate insurance policy

7 Johnson (1953-54); Bagwell and Staiger (2002).

8 An extreme example is the US Morrill Tariff (1861). This tariff sharply raised duties in order to raise revenue for the upcoming war in the United States.

9 There remains no operational definition of protectionism in international law.

10 The GATT discipline is discussed in detail in Jackson (1969), and Baldwin (1971). Mavroidis (2016) adds the case law during the GATT and the WTO years. The GATT-think did not totally solve the problem of defining "protection". It requested from judges (panels) to come up with a workable definition every time they would be asked to pronounce whether domestic policies had been applied in nondiscriminatory (e.g., nonprotectionist) manner. Alas, this is an area where panels did not manage to rise to the challenge (Mavroidis, 2016).

11 Irwin (2015) explains why the fight against the UK imperial preferences was a major target of the US negotiators. The US victory would only come a few dozens years later.

12 Irwin et al. (2008). 
against erosion of the value of tariff bindings. ${ }^{13}$ Tariffs, a negotiable instrument, remained as the only permitted means to protect domestic producers.

\subsection{Neutral Tariff Classifications}

Through the GATT, tariff levels were reduced through reciprocal negotiations. To facilitate this tariff negotiation, a common description of goods for tariffs had to be invented, the successor of which is the current Harmonized Commodity Description and Coding System ('Harmonized System' or HS) classification. ${ }^{14}$ This taxonomy provides a uniform classification of goods with numerical codes. A two-digit number refers to a family of goods (e.g., textiles), whereas a six-digit number, the maximum number of digits permitted in the HS system, identifies a particular species of that good (e.g., shirts with polyester). The HS system classifies products according to their characteristics and properties. The end-use or the manufacturing methods used in production are not relevant, unless that end-use or manufacturing method had an impact on the product's properties. In other words, HS tariff classifications do not reflect social preferences (e.g., produced consistent with environmentallysustainable or labor-friendly standards), but rather product characteristics (e.g., cotton- or polyester).

It did not have to be this way. Tariff classifications can reflect social preferences. In fact, today, some national tariff classifications do. Article 3.3 of the International Convention on the Harmonized Commodity Description and Coding System ("HS Convention) allows for national subclassifications. The EU, and the US and others negotiate at the eight-, ten- and higher digit level classifications. These remain, however, national idiosyncratic classifications. The first attempt to design a multilateral tariff classification that includes social preferences - the WTO Environmental Goods Agreement (EGA) - is under way at the moment of writing. That classification will provide the basis for negotiating further tariff reductions for products in areas such as clean energy, energy efficiency, air pollution control, and environmental monitoring and analysis.

\subsection{Disciplines on NTMs: Insurance against Concession Erosion}

Without negotiation of HS classifications that reflect social preferences, a GATT member that wishes to restrict import of goods or services inconsistent with its environmental, labor, and food safety preferences has two options. The government may block the imports at the border and, if challenged by another member, try to justify its action through recourse to general exceptions to the GATT (Article XX). Or, the regulating government could impose a regulatory measure, such as a sales ban, and, if challenged, explain why that regulatory action is nondiscriminatory. The first option has no advantages at all under the GATT. The burden of proof stays with the regulating state, and it still has to meet the nondiscrimination-test embedded in the chapeau of Article XX of the GATT. In the second case, the complainants carry the associated burden of production of proof, and persuasion. ${ }^{15}$ Unsurprisingly, GATT members prefer to impose regulatory measures that ban sales instead of imposing bans on imports.

13 The negotiating record discussed in Irwin et al. (2008) is clear on this score. The WTO Appellate Body (AB) accepted as much in its report on Japan-Alcoholic Beverages II.

14 The International Convention on the Harmonized Commodity Description and Coding System ("HS Convention") governs the HS. The World Customs Organization maintains the HS, which now more than 200 countries use and covers 5,000 commodity groups and more than 98 percent of the world's trade in goods. See World Customs Organization, What is the Harmonized System (HS)? at http://www.wcoomd.org/en/topics/nomenclature/overview/what-is-theharmonized-system.aspx.

15 Viewed from this angle, it is quite remarkable that the US defended its measures on US-Shrimp under Article XX, when it could have done so under Article III of GATT, by adopting a sales ban on shrimps that had been fished in a manner that prejudiced the life of sea turtles. 
The burden then falls to the GATT (and later the WTO) judge to determine whether the measure is nondiscriminatory. The purpose of our paper is not to debate the quality of case law in this context, beyond noting that the exercise has been fraught. ${ }^{16}$ Defining "protection", especially in the regulatory context, is difficult and dependent on the activity and regulatory context. Trade effects could be the necessary and unintended by-product of pursuing an environmental or other legitimate social objective. A regulation, for example, that bans the sale of cars without catalyst might be motivated by environmental concerns to reduce emissions. It will also exclude from the market all cars that do not carry a catalyst. Protectionist intent is difficult to reveal, since as in prisoner's dilemma, the regulator, the possessor of the private information, has little or no incentive to reveal the true intent of its actions. ${ }^{17}$ Without a demonstrated intent to protect (and/or protectionist effect), many regulatory measures can be interpreted in multiple ways.

\subsection{The Consequence}

The GATT-think that characterizes its framers' ingenious approach to tariffs and border restrictions does not apply in any direct way to regulations and other non-tariff measures. The GATT framers devoted several provisions to the treatment of tariffs (Articles II, XXVIII, XXVIII bis, and indirectly VI, VII, VIII of GATT), but only one provision on the treatment of non-tariff measures, namely, the nondiscrimination requirements in Article III. The agreement is largely unconcerned whether domestic policies and their underlying social preferences are pursued unilaterally. It also does not address the negative externalities for trade and effective regulation that may result from that uncoordinated action.

The nondiscrimination requirement on domestic policies in the GATT exhibits a binary function. Unless the regulatory standards of the importing state have been met, exporters will not access foreign markets even when duties are at zero level. Even excessive legislation passes muster provided that it is nondiscriminatory. The GATT does not attempt to rationalize domestic policies or facilitate their efficiency and effectiveness. As long as the same burden is imposed on domestic and foreign goods, measures satisfy the nondiscrimination requirement. ${ }^{18}$

Could the GATT framers have done better? Perhaps not. Baldwin (1971) has persuasively argued that tariffs were high and regulation mostly nondiscriminatory ${ }^{19}$ in 1947 and, thus, it is understandable that domestic policies were not the focus of GATT framers. Participating governments had little interest in limiting their freedom in areas like product safety for sake of 'a mere trade agreement.' (Hudec, 1990). Social preferences and regulations did not fit easily with the notion of reciprocal negotiations central to the GATT. Workers rights, competition policy, and other issues of economic and social regulation were to be taken up later in the International Trade Organization (ITO), of which the GATT was meant to be a part (Slaughter, 1992). As Horn et al. (2011) shows, when returns become diminishing, trade negotiators are apt to call it a day and leave it to subsequent negotiation(s) and/or adjudicators to 'complete' the contract.

Even with this limited mandate, the GATT produced important benefits. These include binding the negotiated tariff reductions for an extended period, establishing the principle of nondiscrimination in international trade, improving the transparency and predictability of many trade policy measures, and providing a forum for future negotiations and for the peaceful resolution of bilateral disputes (Bown \&

16 See Mavroidis (2016) vol. 2, pp. 447-453.

17 Bagwell and Staiger (2002).

18 Grossman et al. (2013) explain this point in detail. Case law has disturbed the balance struck by the GATT framers. At the end of the day though, the absence of clear methodology and the commission of some judicial errors notwithstanding, more often than not the spirit of what we have described so far has been somewhat respected.

19 This was the case for various reasons. Tariffs represented the preferred instrument of protection, since it is simple and efficient means to do so. Domestic regulation often addressed distortions irrespective of their origin. Furthermore, because tariffs could be used anyway, why should regulation of domestic policies be discriminatory? 
Irwin, 2016). GATT is widely viewed as having facilitated the reduction of tariffs - at least in higherincome nations, which included most of the original 23 GATT member countries.

\section{The WTO and Managing the GATT's Success}

When the original member states signed the GATT in 1947, the objectives were a rules-based global trading system and fewer border restraints on trade. By the 1970s, both goals were well on their way to being achieved. Tariffs had declined dramatically, at least on the industrial goods on which higherincome countries were willing to negotiate. These gains were spurred by reciprocal concessions, extended by the non-discrimination requirement, and enforced by dispute settlement under the GATT. With lower tariffs, the role of regulations and standards as potential barriers to trade became more apparent (Baldwin, 1971).

At the same time, new regulatory institutions arose and social preferences evolved, expanded, and were embedded in government policies in the decades following the post-war era (Levi-Faur, 2005). With economic growth, came an expansion of the middle class in many higher-income nations and a greater interest in quality of life concerns (Inglehart, 2000). The new regulatory institutions and rules that emerged during this time covered the safety of the workplace, the reliability of consumer products, the relations between employers and employees, the fairness of the market, the quality of air, water, and other environmental concerns, and various aspects of national life.

The multilateral trade agenda shifted tentatively in the direction of addressing nontariff measures in the Tokyo Round of the GATT (1973-1979) and the negotiation of "codes." ${ }^{20}$ The Tokyo Round codes were plurilateral agreements negotiated and voluntarily adopted by only some GATT members. The Tokyo Round produced codes with new disciplines on non-tariff issues including subsidies, government procurement, bovine meat, dairy, and technical barriers to the trade in goods (i.e., labeling, packaging, production, and products regulations and standards).

With the start of the Uruguay Round in 1986, higher income countries, which had already achieved significant tariff reductions in their sectors of greatest interest, pushed for disciplines on the emerging priorities of their exporters, such as intellectual property rights and trade in services. Higher-income countries also wanted to update the Tokyo Round codes to address other areas of regulation and to ensure that all members adopted the codes as part of a single undertaking. In exchange, sectors that were still marked by high tariffs and not included in previous GATT rounds-agriculture, clothing and labor-intensive industrial goods - were put on the table to spur the interest of less wealthy countries and their lower-wage exporters. This deal was intended to generate momentum for future multilateral trade liberalization by broadening its focus, both in terms of increasing the number of member countries and the areas to be negotiated.

In that sense, the WTO, which launched on January 1, 1995 after the Uruguay Round, can be seen as an effort to manage the success of the GATT. The results were mixed. More than 70 low- and middle-income countries joined the GATT/WTO since the start of the Uruguay Round. The goods sectors that remained stubbornly outside of the GATT were tamed with the signing of the Agreement on Agriculture, and the Agreement on Textiles and Clothing. With tariffs on their way out of most other sectors, the focus of the WTO shifted to non-tariff measures and barriers, but its approach remained largely one of negative integration. Multilateral trade liberalization at the WTO has largely ground to a halt after the Uruguay Round; the current the Doha Round has stalled since 2001.

The question that the framers of the WTO needed to ask was whether the approach to disciplining non-tariff measures should change from GATT-think with the decline of tariffs and the expansion of

20 A more limited use of plurilateral codes already existed in the GATT. The Kennedy Round of negotiations in the 1960s produced a plurilateral code on antidumping. 
the GATT/WTO membership. Was the priority for disciplines on non-tariff measures still ensuring against erosion of tariff concessions once global tariffs levels were relatively low and countries began unilaterally reducing tariff levels well beyond their bound levels? Or, should there be more positive integration of countries' regulatory objectives and social preferences into multilateral trade cooperation? WTO framers responded with the German word "jein", something between "ja", and "nein", as we explain in what follows.

\subsection{Elaborate Tariff Classifications}

There was no formal move toward greater accommodation of social preferences into the HS system, but countries have been moving in that direction. In the beginning, only the EU and United States had elaborate tariff classifications. Over the years, other WTO members have begun to do the same. Expanded tariff classifications allow countries to target narrower classes of goods for preferential treatment, including those that reflect important social values. On the other hand, with more elaborate tariff classifications, WTO members may advance demanding regulatory standards, which may reduce their possible sources of origin of those goods to a handful of more developed nations. The obligation to extend concessions on these regulation-informed tariff lines to other WTO member states on a nondiscriminatory (most-favored nation) basis may not mean much without a corresponding effort to improve their technical capacity to meet its requirements.

National tariff classifications do not benefit from an irrefutable presumption of legality. They are WTO-compliant only if the classification meets the standard embedded in Article 3.3 of HS, which is that they are sub-classifications of HS classifications at the six-digit level. Case law suggests that it may be permissible to include, inter alia, end uses and consumer preferences in those subclassifications. ${ }^{21}$ Surprisingly, there have been no disputes on this score yet, even though consumers and governments may have different preferences (otherwise there is no need to preempt consumers' choice through elaborate classifications). One reason for the lack of litigation may be the limited advantage afforded by using these classifications to reduce already low tariff levels.

\subsection{Non-Tariff Measures}

The WTO added two agreements (one new, one renewed) to its arsenal on regulations and other nontariff measures. The Agreement on Technical Barriers to Trade (TBT) is an update of the Tokyo round agreement on the same subject, whereas the Agreement on Sanitary and Phyto-sanitary (SPS) measures is a novelty that covers measures protecting human and animal health, and the environment from pests and diseases. The GATT also remained in place and covers transactions that do not fall under the SPS and the TBT Agreements.

The TBT and SPS Agreements mostly function as an insurance policy to preserve the value of tariff concessions. This is particularly true for the SPS Agreement, which was included to guard against reintroducing the EU common agricultural policy (CAP) through regulation. Various WTO members fought long and hard to persuade the EU to reform its CAP. The last thing those members wished to see was the emergence of non-tariff measures in lieu of the CAP's variable duties. ${ }^{22}$

Parts of the TBT and SPS Agreements, however, do more than protect against erosion of tariff concessions. Both Agreements include provisions that promote consideration of the negative impact that unilateral or excessive exercise of regulatory authority might entail, but do not go so far as to oblige WTO members to adopt a particular standard of protection or most efficient measure to achieve the stated social preference.

\footnotetext{
21 Mavroidis (2016) vol. 1, pp. 137 et seq.

22 Mavroidis (2016), vol. 2, pp. 455 et seq.
} 
The TBT Agreement recommends performance- over process-based measures, because there may be gains from having different approaches to meet regulatory objectives (art. 2.8). It requires governments to base their interventions on international standards, if the latter exist and are appropriate to the social preferences pursued (art. 2.4). The TBT Agreement mandates that regulatory measures to be necessary to achieve their objective and to be applied in a nondiscriminatory manner (art. 2.1, 2.2). "Necessary" means that WTO members must, when faced with regulatory alternatives that are equally efficient to achieve the stated social preferences, choose the measure that has less impact on the global volume of goods traded. ${ }^{23}$ In the TBT- and SPS- context, it also means that a WTO member should contemplate the necessity to intervene with its own regulatory measure in the first place. ${ }^{24}$ This obligation is meant to reduce measures that unnecessarily duplicate the regulations of the exporting market or unnecessarily diverge from the international standard. For this reason, international standards are presumed necessary under the TBT Agreement (art. 2.5). Finally, the TBT includes a mix of legally binding obligations (like obligations to notify and explain national regulations) and a best efforts requirement to pursue mutual recognition, equivalency, and harmonization initiatives with other WTO members (art. 2.5-2.7).

The SPS Agreement goes even further. Besides fulfilling all the same requirements that are in the TBT Agreement, WTO members must also adopt science-based measures and be consistent in formulating their policies (art. 2.2). Science is of course, the universal language, and often the best indicator that a measure has not been enacted with protectionist intent. The consistency-requirement reinforces this requirement, since it requires WTO members to treat risks in a comparable manner (art. 2.3).

The provisions on necessity, science, consistency, and international standards in the TBT and SPS Agreements have served as additional proxies (besides the nondiscriminatory application of measures) for suppressing protectionist behavior, but seek to do more. These rules are also meant to discourage measures that have no disparate impact on imports, but are still excessive in achieving their intended regulatory objective. ${ }^{25}$ There is little evidence, however, that these provisions have convinced countries not to adopt unilaterally regulatory measures that are duplicative, unnecessarily divergent, or inefficient. The WTO is still largely in a negative integration mode on regulatory measures and social preferences. Liberalization of investment is of course, a mitigating factor, since foreign investors will lobby host governments and press for adoption of measures consistent with their regulatory interests. But it is only a mitigating factor. The WTO has only now started to take the first steps towards regulatory cooperation.

\subsection{Regulatory Cooperation in WTO}

What is regulatory cooperation and why is it necessary? The term itself is like an accordion. It has been used to mean as little as dialogue and an agreement to notify and consult on a new or proposed regulatory measure or as much as to refer to an obligation to adopt international standards or to recognize or harmonize with another nation's laws. ${ }^{26}$

23 Mavroidis (2016), vol. 2, pp. 493-94

24 Appellate Body Report, United States - Measures Concerning the Importation, Marketing and Sale of Tuna and Tuna Products, WT/DS381/R (May 16, 2012) [hereinafter U.S.-Tuna II (Mexico) AB Report], paras 321-322.

25

Regan (2006) describes the purpose of the TBT and SPS agreements as restraining 'domestically irrational' policies, a natural extension of the overall efforts to suppress protection.

26

(2013) categorizes international regulatory cooperation into eleven different types. These include: informal regulatory dialogue; nonbinding guidelines or principles; incorporation of international standards codes; transgovernmental networks of regulators; mutual recognition agreements; regional trade agreements with regulatory integration provisions; membership in intergovernmental organizations; formal regulatory cooperation agreements; and harmonization through supra-national or joint institutions. 
Trade officials are interested in regulatory cooperation because there are few feasible alternatives for reducing the restraints that nondiscriminatory regulations may impose on international commerce. Unlike tariffs, one cannot (and should not) eliminate regulation. Regulations are essential tools with which to promote public health and safety, safeguard the environment and rights of citizens, and ensure the proper functioning of markets. Excessive, duplicative, or unnecessarily divergent regulations and conformity assessment procedures, however, can thwart the interoperability and effectiveness of regulatory systems, raise costs for businesses and citizens, and disadvantage foreign suppliers, which lack the inside knowledge of their counterparts (Sykes, 1999). Nondiscrimination, a key tenant of GATT-think, is limited in addressing this problem.

Prohibiting non-tariff barriers to trade ("negative integration") has helped open markets, but has not yielded consistent, efficient, and effective oversight. OECD (2013) has identified three categories of costs from international regulatory incoherence: (1) informational costs of identifying and understanding different regulations; (2) specification costs of complying with divergent and duplicative regulatory standards in export markets; and (3) conformity assessment costs of demonstrating compliance with standards. Absent cooperation or the ability to pay these adjustment costs, foreign producers and suppliers, especially small and medium-sized enterprises, face market exclusion (Maskus, 2005).

There are three basic scenarios where international regulatory incoherence, even when not directed against foreign producers, may occur and not be effectively restrained by the provisions in the SPS and TBT Agreements. First, regulatory authorities may impose duplicative rules and conformity assessment procedures. This scenario may result from lack of awareness or concern with the trade costs of these redundancies. National regulatory authorities are primarily accountable for fulfilling their mandate to domestic constituencies, not to foreign producers. Duplicative regulation may also arise when a national regulator lacks confidence in its foreign counterpart to monitor and enforce the rules competently. It may also be the product of rent-seeking, used to generate fees to support regulatory agencies and the staff salaries devoted to overseeing and enforcing the rule.

Second, regulatory authorities may impose divergent, but similarly stringent rules. This scenario is most likely to occur among states at similar levels of economic development. Even among otherwise like-minded democratic, advanced industrialized economies, regulatory differences are inevitable. Regulation starts out as the answer to a domestic problem, developed within a preexisting national regulatory framework. So while the social preferences and attitudes toward risk may be similar in two countries, governments may still devise different rules and enforce them differently because they are better suited to their particular institutional structures and rulemaking procedures (Drezner, 2008).

Third, regulatory authorities may impose divergent rules and conformity assessment procedures with different levels of stringency. This scenario is most likely to occur with states at different levels of economic development. At low-levels of income, citizens and their governments tend to prioritize economic growth and efficiency over stringent domestic regulatory oversight. ${ }^{27}$ As personal incomes increase, many lower-income nations are working to raise regulatory standards and improve oversight, especially over goods and services destined for export, but face capacity, resource, and governance challenges in doing so. ${ }^{28}$

The regulatory incoherence in each of these scenarios does not run afoul of WTO restrictions on discriminatory measures or the provisions in the TBT and SPS Agreements on using necessary,

27 Drezner (2008) compares stringent regulation to a luxury good with high-income elasticities of demand.

28

National Academy of Sciences. 2012; Joe Nocera, The Baby Formula Barometer, New York Times, July 26, 2013. See also World Bank, 2006 World Bank, China's Compliance with Food Safety Requirements for Fruits and Vegetables: Promoting Food Safety, Competitiveness and Poverty Reduction, World Bank, Beijing/Washington, DC (2006) (describing a two-tier regulatory model in which products for export are fairly well regulated, but those for domestic consumption are not). 
science-based, and consistent regulatory measures and international standards where appropriate. In other words, the reasons for the incoherence are not protectionist or even domestically irrational, but the outcome remains inefficient for trade and, often, for achieving effective international regulatory oversight. The TBT and SPS Agreements include mutual recognition and equivalence provisions to help address the problem, but they are limited to best endeavors. ${ }^{29}$

It is in these scenarios where international regulatory cooperation is necessary. Dialogues and cooperation agreements, for instance, can help improve transparency, sensitize trading nations to others' needs and costs, and advance coordination among regulators and between regulators, businesses, and trade officials. ${ }^{30}$ Peer-to-peer regulatory networks, consensus best practice guidelines and principles, and intergovernmental organizations promote work sharing and build regulatory and enforcement capacity, making it cheaper for nations to adopt policy reforms and maintain consistent regulatory oversight. ${ }^{31}$ At the same time, mutual recognition agreements and regional trade deals can help increase the benefits of adopting convergent, adequate, and efficient regulations and conformity assessment by reinforcing their link to market access. ${ }^{32}$

\subsubsection{Cooperation in WTO on non-tariff measures}

The WTO has taken some tentative steps towards establishing regulatory cooperation with the advent of the TBT- and the SPS Agreements. ${ }^{33}$ Both agreements include measures to promote regulatory transparency and adoption of international standards. These measures facilitate trade and regulatory objectives by providing predictability for exporters and investors and simplifying regulatory compliance. $^{34}$

Both agreements also provide a procedure for raising specific trade concerns (STCs), a more intensive avenue for engagement on nontariff measures that stops short of formal dispute settlement. STCs are formal requests for clarification by a WTO member regarding another member states' TBTor SPS-related measure, whether that measure was notified or if the other member state learned of measure without notification. STCs could lead to informal settlement or provide the basis for a formal dispute. ${ }^{35}$ STCs represent a form of cooperation at the very beginning of the spectrum that could lead

29 TBT Agreement, art. 2.7; SPS Agreement, art. 4.

30 Examples of dialogues include the Transatlantic Business Dialogue (TABD) and the Transtlantic Consumer Dialogue (TACD). Examples of cooperation agreements include the Canada-U.S. Regulatory Council (RCC) and the Rapid Alert System for Nonfood Dangerous Products (RAPEX), established pursuant to the EU-China Regulatory Cooperation Framework. RAPEX has investigated and helped constructively resolve thousands of product safety concerns.

31 Good examples of peer-to-peer regulatory networks include the Basel Committee on Banking Supervision and the Africa Medicines Regulatory Harmonization initiative, which is supported by the African Union, the World Health Organization, and a World Bank Trust Fund. The Asia Pacific Economic Cooperation (APEC) forum and the Organization for Cooperation and Economic Development (OECD) put forward a frequently cited voluntary checklist to promote regulatory quality and efficiency. See APEC-OECD Integrated Checklist on Regulatory Reform, 2005, 1-36. Other institutions besides APEC and OECD involved in promoting regulatory cooperation and common standards include the International Organization for Standardization (ISO).

Examples of mutual recognition agreements include the Trans-Tasman Mutual Recognition Agreement, which has had the notable output of the Food Standards Australia/New Zealand (FSANZ), an effort to cooperate on the development of food standards before the adoption of national standards. Examples of regional trade agreements include Comprehensive Economic and Trade Agreement (CETA), a pending deal between Canada and the EU with extensive provisions on product standards, mutual recognition, and regulatory cooperation.

33 Mavroidis and Wolfe (2015) discuss this issue in detail

34 WTO, Agreement on Application of Sanitary and Phytosanitary Measures (SPS), 1994, Art. 2.3, 3, 5.4; WTO, Agreement on Technical Barriers to Trade (TBT), 1994, Art. 2.2, 2.4, 2.8; WTO, General Agreement on Trade in Services (GATS), 1995, Art 2.2, 2.3, 5.6.

35 Transparency and dispute settlement are complements as they are substitutes. Through increased awareness of measures, a WTO member might wish to drop its original complaint. It could also, because of increased awareness, take the view 
to common rules. Since advent of the WTO, there has been an upward trend in the STCs filed annually, from 4 in 1995 to 85 in 2014 (Wijkström, 2015).

WTO members further discuss issues regarding the administration of regulatory measures in the committees created under the aegis of the SPS and TBT Agreements. Annex 3 of the TBT Agreement includes the Code of Good Practice (CGP) for the Preparation, Adoption and Application of Standards, which encourages standard setting bodies to be transparent and promulgate nondiscriminatory, performance-based, and non-duplicative standards. In 2000, the WTO Committee on Technical Barriers to Trade (TBT Committee) agreed to additional principles for the work of international standard setting bodies, which include transparency, openness, and an impartial and consensus-driven approach that promotes effective and relevant standards and incorporates the concerns of developing countries (WTO, 2000). The TBT Committee has also promoted the use of good regulatory practices in workshops and in its fifth triennial review. ${ }^{36}$ Good regulatory practices promote the exchange of information and more coordination among regulators, standard setting bodies, and trade officials. In 2014, the SPS Committee launched a mechanism to mediate rising trade tensions over food safety and animal-plant health measures. ${ }^{37}$

At this stage, it is difficult to evaluate the impact of WTO efforts on regulatory cooperation, but one should probably not expect too much. Without a greater mandate and more institutional support, these WTO efforts seem more likely to serve as guideline for unilateral actions by members, rather than the first step towards establishing a forum for cooperation between members.

\subsubsection{Tariffs}

Regulatory cooperation at the WTO is taking place in the realm of tariff classifications as well. Although not formally under the auspices of the WTO, for the time being at least, negotiation of the EGA were launched in July $2014 .^{38}$ The purpose of the negotiation is to agree on preferential tariffs for goods that protect environment. To do this, negotiators have to agree on classifications that reflect regulatory processes that promote environmental protective goods and provide tariff advantages to those goods that conform to the agreed process.

\section{The Changing Political Economy of Trade, Regulatory Cooperation, and Social Preferences}

The way the world trades is changing. Not only are trade barriers now predominantly nontariff measures, there are also fewer goods and services that originate from any one country or any one supplier. More trade occurs via global value chains (GVCs), in which different firms in different countries undertake different parts of the process of producing a good or service. GVCs started in the 1960s when international companies took advantage of lower tariffs, the containerization of shipping, and better information and communication technologies to slice up and outsource parts of their manufacturing supply chains to lower-cost, specialist suppliers abroad. In the 1990s and 2000s, the

\section{(Contd.)}

that it has a strong case before a WTO panel. In similar vein, we should also note that "trade policy begins at home", as Helmer and Wolfe (2007) have stated. National attitudes will of course, influence the conduct of international cooperation. The purpose of our paper is to see how far can we go in terms of cooperation building on national idiosyncratic elements.

36 Committee on Technical Barriers to Trade, Summary Report of the WTO TBT Workshop on Good Regulatory Practice (G/TBT/W/287), World Trade Organization, June 6, 2008, 1-28; WTO Committee on Technical Barriers to Trade, Fifth Triennial Review of the Operation and Implementation of the Agreement on Technical Barriers to Trade under Article 15.4 (G/TBT/26), Nov. 19, 2009, 5-6.

37 For more details, see https://www.wto.org/english/news_e/news14_e/sps_10sep14_e.htm.

38 Started 14 now 17: Australia; Canada; China; Chinese Taipei (Taiwan); Costa Rica; European Union; Hong Kong, China; Iceland; Israel; Japan; Korea; New Zealand; Norway; Singapore; Switzerland; Turkey; United States of America. 
shift to GVCs expanded to services and to sectors ranging from food production to medical R\&D. With the 2008 global economic crisis, GVCs evolved again, becoming more regional and reorienting around large emerging economies with rising production capabilities and more domestic consumer demand (Gereffi, 2014). The inputs and components in GVCs comprise 56 percent of the global goods trade and 73 percent of the services trade (WTO, 2011).

The rise of GVCs has had significant benefits. ${ }^{39}$ Unbundling affords businesses the opportunity to scale economies, implement just-in-time production, and greater flexibility in meeting consumer demand. Consumers gain more affordable goods and services. GVCs have contributed to the shift of employment in labor-intensive sectors away from higher-income nations - a painful and unsettling process for the workers and communities affected - but it has also created specialized, higher-wage jobs in those nations coordinating production networks and in product design, branding, and other large-margin activities. The unbundling of production has also reduced the barriers to lower-income countries competing in the world economy, which enable those nations to industrialize through GVCs and to lift tens of millions of their citizens out of abject poverty.

Sustaining and expanding these benefits of GVCs requires consistent, adequate and efficient regulation. GVCs involve the cross border movement of capital, knowledge, and intermediate services and parts. As the number of countries and cross-border transactions in GVCs multiply, so do the economic costs of inefficient, duplicative, and divergent regulations. The proliferation of uncoordinated regulations challenges even sophisticated multinationals. The high costs of regulatory compliance can keep small and medium-sized businesses out of GVCs altogether. Divergent rules on data storage and analysis and product testing can act as localization requirements, making production in other jurisdictions infeasible (OECD, 2015). According to the WTO World Trade Report (2009), one-third of the global trade in goods (estimated $\$ 15.8$ trillion in 2008) was affected by standards that differ across jurisdictions.

Consistent, adequate, and efficient regulatory oversight is also important to the viability of GVCs as a means of economic development. Goods and services must ultimately satisfy the social preferences of consumers and the standards of national regulatory authorities and retailers in end-user markets. Inability to comply reliably with food safety rules, labor standards, or environmental requirements can lead to border detentions and import bans, liability and reputational damage, and contractual penalties for manufacturers and suppliers. It can deter foreign direct investment in countries. Particularly in export driven lower-income economies, the costs of regulatory noncompliance can be significant. In the context of GVCs, adequate, consistent regulatory oversight no longer just ensures social preferences; it is an investment in economic development and trade facilitation (National Academy of Sciences, 2012). ${ }^{40}$

Health, labor, financial and environmental policymakers likewise have an interest in adequate, consistent, and collaborative international regulation. In the GVC context, regulatory agencies cannot do their jobs without the help of their counterparts. Imports that the U.S. Food and Drug Administration regulates, for example, have grown nearly six fold (from six million to 35 million shipments) over the twelve years and now involve more than 300,000 facilities in more than 150 different countries. ${ }^{41}$ There are legal and practical limits on inspecting such a multitude of producers and suppliers. Border and port surveillance can supplement but not replace oversight, control, and surveillance by local regulators and industry. In sectors involving global public goods - such as

39 See the excellent analysis of this issue in Hoekman (2014).

40 See also Miet Maertens \& Jo Swinnen, Food Standards, Trade, and Development, 3 Review of Business and Economics 313 (2009); World Bank, Food Safety and Agricultural Health Standards: Challenges and Opportunities for Developing Country Exports, Report No. 31207 (2005); Spencer Henson, Food Safety Issues in International Trade in Food Safety in Food Security and Food Trade (2003).

41 U.S. Food \& Drug Administration (2012). 
stemming climate change, financial contagion, or pollution - regulatory objectives cannot be met without international coordination. International collaboration helps regulators gather information, develop, and share best regulatory practices and tools, and to build the knowledge base for effective regulation (De Búrca, Keohane \& Sabel, 2014; Sabel, 2015). For all these reasons, and in many sectors, regulatory oversight in one country increasingly depends on the adequacy and consistency of regulatory oversight in other countries (Bollyky, 2009, 2012, 2015).

\subsection{The Case for a Positive Integration Strategy on Trade \& Regulation}

If internationally consistent, efficient, and adequate regulatory oversight provides compound benefits, it may seem unnecessary for governments to engage international regulatory cooperation to achieve it. Why don't governments undertake the necessary regulatory reforms unilaterally? Here, there is a partial analogy to GATT-think and enlightened mercantilism helps demonstrate the need for international regulatory cooperation and the reasons why negotiators and regulators need to pursue that objective together.

There are regulatory reforms that government may undertake unilaterally that have benefits for trade. Countries may increase their export competitiveness by unilaterally adopting good regulatory practices. ${ }^{42}$ Improving the quality, transparency, and predictability of regulatory measures helps domestic actors and importers alike (Jacobs and Ladegaard, 2010). Over time, adoption of administrative law practices like regulatory impact assessment might also assist exporters if it brings the trade and regulatory communities closer and sensitizes both sides to each other's concerns (Coglianese, 2016).

Yet, as in GATT-think, structured international regulatory cooperation provides benefits that may not be easily achieved unilaterally: predictability, greater accountability for backsliding, iterative engagement on deepening integration, and gains in efficiencies from increased scale (Irwin, 2015). Regulations are also not like tariffs, which can be effectively liberalized unilaterally. Regulations are dynamic, with rules and their enforcement changing in response to emerging political and market demands. Unilateral adoption of good regulatory practices can only do so much to spur freer trade if other nations also do not reciprocate and maintain the internationally consistent, adequate measures and shared conformity assessments that both exporters and regulators need in this GVC-dominated economy (Bollyky, 2012).

Further, international, rules-based cooperation has an important role in improving domesticdecision making. Even in democratic governments, domestic interests may undermine or subvert good regulatory practices such as the obligation to provide notice and comment and assess the cost-benefits of proposed rules. The accountability and transparency that comes with iterative international regulatory engagement on shared goals provides an important restraint on that occurring.

As in GATT-think, international agreements to advance regulatory cooperation also may create the political support and domestic constituencies for making the necessary policy reforms. In this context, trade and regulators need each other.

Trade negotiators are unlikely to advance their priorities on improved international regulatory coherence without the support and active participation of regulatory officials. The reasons are twofold. First, consistent, efficient regulatory oversight depends as much on how rules are interpreted and enforced as the rules themselves. Even with the support of a country's leadership, it is difficult in a top-down approach to mandate and maintain iterative, cooperative behavior. Meaningful, sustained progress is more likely if the objective is addressing transnational regulatory priorities as well as facilitating international commerce.

42 OECD (2005); World Bank (2012); OECD (2002). 
Second, without the engagement of regulatory authorities, concerns about diminishing cherished social preferences would make the already difficult politics of trade liberalization unworkable. Fears over food safety and genetically modified organisms have driven a fierce backlash in the EU against the Trans-Atlantic Trade and Investment Partnership (TTIP) negotiations. Popular support for greater global economic integration is more likely to occur in a regulator-supported effort to ensure that freer trade also results in safer goods, a more protected environment, and more assured public health and welfare.

Conversely, regulatory cooperation initiatives have better prospects if pursued in partnership with trade officials and aligned with the needs of exporters and their governments. Here too, the reasons are twofold. First, regulatory agencies are chronically underfunded and domestic in their orientation. Few of these agencies have the resources, staff, and mandate to pursue international cooperation and capacity building. Trade talks provide the structure, resources, and high-level political commitment that international regulatory dialogues often lack.

Second, advancing international cooperation in regulatory dialogues alone is unlikely to exploit the opportunity that the rise of GVCs presents. The challenge of achieving international cooperation is greatest in areas where (1) regulatory regimes are mature and (2) the responsible agencies in large consumer-markets disagree (Drezner, 2008). Even non-substantive changes, such as adoption of common forms or sharing of inspection reports, impose adjustment costs on regulatory agencies with well-established systems in that area. The adoption of international standards in many heavily regulated sectors has been slow and in high-income countries, such as the United States, poor. ${ }^{43}$ Regulator-to-regulator dialogues such as the International Conference on Harmonization of Technical Requirements for Registration of Pharmaceuticals for Human Use can make progress, but have required decades to do so. ${ }^{44}$

The rise of GVCs provides a powerful, but time-limited incentive for regulatory agencies to incur adjustment costs in order to spread their norms and standards to the many other countries involved in producing goods and services for import in their markets. The incentive exists because adoption of common rules and certification regimes helps spread those rules internationally, by making it easier for exporters and investors in third-party countries to achieve economies of scale by complying with regulations in multiple large consumer markets (Vogel, 1995; Maertens and Swinnen, 2009; Greenhill et al., 2009).

That incentive is time-limited because it may become harder to drive adoption of international norms as consumer spending in emerging economies grows and these markets become a bigger target for exporters. Further growth and a shift to more domestic consumption in emerging economies are positive trends, but adding more large-consumer markets will make reaching agreement on regulatory standards harder, especially in the absence of an effective multilateral institutional support. The emerging trends of large multinational companies localizing production in big end-use markets ${ }^{45}$ and the increasing reliance of these companies on private standards, third-party certifications and proprietary quality management systems only compound that challenge.

\subsection{Bilateral and regional trade initiatives on regulatory cooperation}

There is no better argument that the WTO does not do enough in the realm of regulatory cooperation and social preferences than the proliferation of preferential trade agreements (PTAs) that seek to

\footnotetext{
43 See, e.g., Donna Roberts \& Tim Josling, Tacking the Implementation of Internationally Agreed Standards in Food and Agricultural Production, International Food \& Agricultural Trade Policy Council (2011).

44 Institute of Medicine (IOM) 2013. International Regulatory Harmonization Amid Globalization of Drug Development: Workshop Summary. Washington, DC: The National Academies Press.

45 Immelt (2016)
} 
address these topics. In 1990, there were approximately seventy active PTAs; today there are more than 500. ${ }^{46}$ The explosive growth in the number of PTAs began with the end of the Uruguay round and the increased relative importance of non-tariff measures as potential restraints on trade. ${ }^{47}$ Roughly 60 of these PTAs have terms that go beyond the WTO TBT commitments; fifty have SPS commitments that exceed those in WTO agreements. (WTO, 2011). Countries with more extensive participation in GVCs are more likely to enter into these 'deep integration' PTAs and more likely to reap the benefits of doing so (Orefice \& Roca, 2014).

The four major PTAs under negotiation at the time of writing - the Regional Comprehensive Economic Partnership (RCEP), the Trans-Pacific Partnership (TPP), the Trade in Services Agreement (TISA) and the TTIP - all include efforts to advance regulatory cooperation beyond disciplines on nondiscrimination. Serious regulatory cooperation also occurs in the International Organization for Standardization (ISO) and other standard-setting institutions that include trade facilitation and promoting common standards in their mandate.

To date, the most ambitious regulatory cooperation efforts have occurred in PTAs among likeminded nations with regional ties. The EU has pursued regulatory integration among its 28 member states through a wide variety of means including mutual recognition, harmonization, and cooperative approaches such as joint reviews. The United States has launched regulatory cooperation councils with Canada and Mexico (Steger, 2012). Most of the Comprehensive Economic and Trade Agreement (CETA), the pending deal between Canada and the EU, is devoted to product regulation, mutual recognition, and procedures for regulatory cooperation rather than reducing tariffs and other border restraints. $^{48}$

While the like-mindedness of participating states often helps advance regulatory cooperation, it is possible to achieve among heterogeneous trading partners as well. Developing countries have agreed to environmental commitments in PTAs, when those states have not exhibited similar eagerness to do so at the multilateral level. ${ }^{49}$ One reason for doing so might be the additional trade gains afforded in a PTA. The intensity of cooperation might differ, however, among heterogeneous trade partners. Likeminded trading partners have proven more willing to agree to binding disciplines, whereas this has not necessarily been the case between unlike-minded players. ${ }^{50}$ Still, nonbinding commitments may be useful to sensitize trading partners to the worries of their counterparts, to encourage information exchange on the rationale for the regulatory intervention, and to set the stage for more rigorous cooperation in the future.

The prospects for regulatory cooperation are not limitless even when pursued with like-minded partners. Policy independence and regulatory sovereignty were among the reasons (along with antiimmigration) cited in the United Kingdom's June 2016 vote to exit the EU. ${ }^{51}$ The 2007 initiative by Australia and New Zealand to create the Therapeutic Products Authority, a joint regulatory agency for medicines and medical devices, failed. ${ }^{52}$ Previous initiatives to improve EU-U.S. regulatory

46 Limão (2016).

47 Mavroidis and Sapir (2015).

48 The fate of this agreement is now in doubt, following the decision at the EU-level to condition its acceptance upon a vote by national parliaments. France and Germany have already indicated that they will proceed with a vote of the agreement before their respective parliaments.

49 See, e.g.,the US-Peru Free Trade Agreement, chapter 18 (2006) as an illustration of this effect.

50 Horn et al. (2010) offer some examples to this effect.

51 "Dreaming of Sovereignty." The Economist [New York] 10 Mar. 2016. Print.

52 Australian Government Department of Health: Therapeutic Goods Administration. 2007. Australia New Zealand Therapeutic Products Authority (ANZTPA) postponed [Press release]. https://www.tga.gov.au/media-release/australianew-zealand-therapeutic-products-authority-anztpa-postponed 
cooperation have made little progress. ${ }^{53}$ The near-term prospects for a successful conclusion of the TTIP talks do not look good at the time of writing.

Where regulatory cooperation has occurred, however, it has brought real benefits to like-minded trade and regulatory partners. Association of Southeast Asian Nations (ASEAN) countries have used to mutual recognition agreements (MRAs) and cooperation on standards, technical regulations, and conformity assessment to promote themselves as a GVC hub (WTO, 2011). Transatlantic cooperation initiatives may have led to few regulatory changes, but they have helped reduce trade friction. ${ }^{54}$

\subsection{PTAs are a second best solution}

Deep integration PTAs are not entirely outside the ambit of the WTO, since free trade areas and customs unions operate within the four corners of the multilateral trading system. But, it is still important to 'multilateralize' the progress on international regulatory cooperation occurring in PTAs and regional economic communities and bring into the WTO. Here is why.

PTAs are a second-best solution to the problem of achieving freer trade and better regulation because these agreements do not encompass the range of countries in global commerce. ${ }^{55}$ The organization of production and trade into international value chains and networks means that end products are affected by many regulatory jurisdictions. Those jurisdictions are diverse, including nations at different stages of economic development and some with relatively nascent regulatory agencies. ${ }^{56}$ Agreements with rules that do not span all these economies cannot effectively advance global integration and efficiency, particularly in sectors dominated by GVCs and dependent on crossborder data flows and digital commerce. ${ }^{57}$

Pursuing international regulatory cooperation on a multilateral basis and within WTO offers important advantages. It avoids the need to introducing multiple parallel discussions on regulatory and trading partner counterparts. It also takes advantage of the process for regulatory convergence, albeit rudimentary, that is already in place at the WTO.

Many developing countries, especially the lowest-income nations, are generally not included in RCEP, TPP, or the other PTAs with ambitious commitments on regulatory cooperation and coordination. The EU has agreements that include regulatory cooperation with African countries, but they are generally not binding (Horn, Mavroidis, Sapir, 2010). The PTAs that involve low- and middle-income countries do not include particularly 'deep' or enforceable regulatory commitments or go beyond those in WTO agreements (WTO, 2011; Horn, Mavroidis, Sapir, 2010). There has been some targeted engagement between the trade and regulatory agencies of varying levels of economic development, especially on food safety and in the Asia-Pacific Economic Cooperation (APEC) Forum, but progress has been slow. ${ }^{58}$

53 Akhtar, Shayerah I \& Jones, Vivian C, 2014. Transatlantic Trade and Investment Partnership (TTIP) Negotiations, Report for Congress, Congressional Research Service, Washington D.C., p. 26-28.

54 Ahearn, R. J., Transatlantic Regulatory Cooperation: Background and Analysis, Report for Congress, Congressional Research Service, Washington D.C., 2009, pp. 16-17.

55 PTAs across countries at different stages of economic development display the lowest level of integration on TBT and SPS regulation. WTO (2011), pp. 141-142.

56 See Baldwin (2012) demonstrating the range and diversity of countries involved in GVCs and their degree of engagement.

57 Howse (2015) has questioned whether the deep integration rules in some PTAs on intellectual property and domestic regulations and standards is consistent qualifies under the GATT Article XXIV, which exempts disciplines in PTAs that establish preferential tariffs among the parties from compliance with WTO MFN.

58
APEC
Food
Safety
Cooperation
Forum
(FSCF),

http://www.foodstandards.gov.au/science/international/apec/Pages/default.aspx 
The relative lack of engagement of lower-income nations in PTAs and other meaningful international regulatory cooperation initiatives is important because the avenues for unilateral liberalization are limited in the regulatory context. After the advent of the WTO, the lack of progress on the Doha Development Agenda, the next round of WTO negotiations, did not prevent emerging economies from unilaterally reducing tariffs and barriers to investment in order to better compete in a world economy dominated by GVCs. ${ }^{59}$ In the regulatory context, as discussed above, unilateral approaches are more limited.

\section{The New WTO Think}

In a global economy increasingly dominated by GVCs, picking between freer trade and better regulation is increasingly a false choice. Pursuing regulatory cooperation as a strategy for trade liberalization (and vice versa) offers a more promising way for policymakers and negotiators to advance both economic objectives and social preferences on worker safety, a cleaner environment, and healthier, more sustainable products. It is the present alternative -trade officials and regulators operating unilaterally and in parallel - that leaves the fulfillment of those social preferences more at risk and international commercial goals unmet.

In this environment, the original precepts of GATT-think - reducing the negative externalities that result from uncoordinated and non-transparent actions in a trading system with many partners remains as relevant as ever. But, the corporate governance of the GATT/WTO must change to reflect the decline in tariffs and the other traditional barriers to commerce and the emerging challenges of advancing trade, regulation cooperation, and social preferences in a global economy dominated by GVCs. We refer to this integration strategy as the "new WTO think". In what follows, we explore the parameters of that concept, and provide our 'nudge' for a serious discussion on WTO institutional reform.

\subsection{The Need for Changes in the Corporate Governance of WTO}

The rules and procedures of the WTO were designed for a different global economy in which mostly finished goods moved across national borders. With the rise of GVCs, tariffs and other border restraints matter less and the protection of investments and intellectual property, and free flow of components, services, and people matters more. As a result, effective trade rules and the institutions that support that trade must also evolve.

A focus on market access, simple and broadly applied rules, and dispute resolution will not advance the deeper integration that is increasingly required in the world economy. Nondiscrimination and reciprocity cannot assure market access when it is conditioned upon satisfying country-specific regulatory standards and social preferences (Antras and Staiger, 2015). The availability of binding dispute resolution will do little to attract the active engagement of regulatory authorities in international cooperation, when those regulatory authorities have bitterly resented past WTO reviews of their choices.

\subsection{A Strategy for the New WTO Think}

While the negative integration approach of GATT/WTO may be less relevant, the role for the multilateral trade institution remains critical and unlikely to be supplanted by PTAs. Accordingly, the WTO should be strengthened and supported.

59 Baldwin, Richard, Unilateral Tariff Liberalization, NBER Working Paper No. 16600 December 2010. 
The challenge is doing so at a time when global economic power is increasingly diffuse and there is little appetite for empowering a supranational institution to reduce the market segmenting effects of regulatory policies and social preferences (Hoekman, 2016). This will require supplementing the traditional approach of the GATT/WTO - fixed, universal rules subject to binding dispute resolution with the opportunities for interested members to pursue shared social preferences, plurilateral agreements, outside partnerships, and multilaterize the regulatory cooperation occurring via PTAs and regional economic communities.

\subsubsection{Social Preferences Advance Trade and Regulatory Cooperation}

Advancing international trade liberalization has emerged as an important way to pursue social preferences. The reverse is also becoming true. ${ }^{60}$ The WTO should embrace and reinforce this positive link between trade and social preferences, wherever it exists, to advance multilateral agreements on regulatory cooperation.

An increasing number of PTAs, particularly those involving the United States and EU, advance social preferences such as labor and environmental protections, human rights, rule of law, and other aspects of public governance. ${ }^{61}$ The trend began with the North American Free Trade Agreement as a way to resolve political differences in the United States over trade. In the most recent iteration, the TPP, many of the labor and environmental measures are enforceable and subject to dispute resolution. Promoting social preferences as part of PTAs spreads the benefits of trade liberalization, discourages the worst mistreatment of workers and the environment, and builds public support for trade deals (Elliott, 2012).

Conversely, the desire to advance shared social preferences has also spurred interested states to pursue trade initiatives in sectors of concern. The EU, for example, established a Forest Law Enforcement Governance and Trade Initiative to engage lower-income nations in promoting trade in legal timber, increase the market demand for sustainable forestry, and reduce the supply of illegally harvested timber (Shaffer, 2015).

Social preferences are particularly important to trade initiatives in the regulatory cooperation context. Shared preferences provide the basis for establishing a broad framework of shared goals that may engage the active support and participation of regulators. These regulators, in turn, have the sector-specific understanding and mandate to implement, monitor, and maintain meaningful cooperation (De Búrca, Keohane \& Sabel, 2014). The alternative of advancing internationally consistent, efficient, and effective regulations without embracing a larger role for social preferences and norms in WTO agreements seems hopeless.

Trade disciplines, like most laws and regulations, are generally less effective when they require taking iterative, positive action instead of just refraining from unwanted behavior. Compliance with the notification or technical transfer requirements in trade agreements, for example, has been poor (Maskus, 2012; Josling \& Roberts, 2011). Mandating that regulators cooperate or consider the trade impact of their proposed rules is likely to be less effective than providing a workable framework for interested states to advance shared social preferences and consistent, effective, and efficient oversight in commercially important sectors.

The WTO has taken a tentative step in this direction with the negotiation on an EGA. This plurilateral agreement is to be concluded between the EU, United States, China, and fourteen other WTO members accounting for nearly 90 percent of the world's trade in environmental goods. The

60 Benjamin Friedman makes a related argument with regard to the link between economic growth and advancing moral benefits, which he describes as bidirectional and including improving the environment, reducing poverty, promoting democracy, and making for a more open and tolerant society, Friedman (2005).

61 We reference here PTAs that the EU has entered with other nations, not the EU integration process itself. 
core of the agreement is the objective to reduce tariffs on list of 54 environmental goods identified by the APEC forum. ${ }^{62}$

In addition to embracing the social preferences of interested members to advance trade and regulatory goals, the EGA negotiation sets two other precedents that should be more widely embraced: the renewed use of WTO plurilateral agreements and the effort to multilateralize progress that occurred first on a bilateral or regional basis.

\subsubsection{Variable Geometry}

The WTO counts 164 members. They represent a very heterogeneous whole, ranging from Switzerland, Norway and Liechtenstein to the least developed countries in the sub-Saharan Africa. The social preferences of each member are of course, defined endogenously and depend, in part, the capacity of each member to finance the necessary regulatory policies to give effect to those preferences. Regulations reflect the culture, religion, the particulars of legal system, and the relative homogeneity of that society. Whereas some social concerns are almost universal (climate change), others are quite local (pollution of a lake shared between two WTO members). Under these circumstances, it is highly unlikely that regulatory cooperation will involve all its members.

The current WTO-think is based on the idea of "single undertaking," in which all members adopt agreements. The WTO, with the exception of the Agreement on Government Procurement (GPA), has, for all practical purposes, moved away from the Tokyo Round model of plurilateral integration. Some criticized this Tokyo Round model of integration as increasing transaction costs for WTO members. This was a rushed judgment. Yes, different WTO members undertook different obligations in the Tokyo Round. But the advantage of that approach was the increased legitimacy. Each trading nation agreed to the commitments with which it could live. What we recommend here is, in a nutshell, a return to that approach, at least on the issue of regulatory cooperation.

The WTO should encourage the formation of plurilateral agreements, ${ }^{63}$ a design that, unlike free trade areas, keeps the umbilical cord between international regulatory cooperation and the multilateral trading regime tight. Intense regulatory cooperation is taking place within free trade areas, especially among like-minded partners. In light of this, it appears that trading nations gave up on the Tokyo round approach of Codes too soon. Those Codes evolved at a moment when WTO agreements on nontariff barriers became pressing issue, and when agreement across all GATT members would have been impossible. That same dynamic is even more pronounced today.

The advantages of WTO plurilateral agreements over PTAs are that the former provide greater transparency, input, and an explicit path to accession to non-party WTO members in the future. They are also less likely than PTAs to impose negative externalities on third countries (Hoekman and Mavroidis, 2013, 2014).

There are two ways in which a subset of WTO Members may currently undertake additional commitments and trade liberalization - critical mass agreements (CMAs) and plurilateral agreements (PAs). A CMA is an agreement in which negotiated disciplines apply only to a subset of WTO Members, but its benefits are implemented on a most-favored nation (MFN) basis and, thus, must apply to all WTO Members. The significant advantage of CMAs is that these agreements do not require unanimous approval of the full WTO membership. The disadvantage of CMAs are that they allow free-riders and MFN disciplines are an uneasy fit with many forms of cooperation that depend on like-minded regulatory agencies with similar capacities (Bollyky, 2015).

62 APEC Leaders Declaration (2012), List of Environmental Goods, Annex C.

63 Both Bollyky (2012), and Hoekman and Mavroidis (2015) have offered arguments why regulatory coherence can be easier pursued across like-minded countries. 
In contrast, neither the benefits nor the commitments undertaken in PAs extend to non-signatories. The major other advantage of PAs is, unlike CMAs, clear legal authority exists to extend and deepen WTO commitments on regulatory matters in areas other than services. The major disadvantage of PAs, however, is that their incorporation into the WTO must occur "exclusively by consensus" of the full membership, which greatly undermines the value of proceeding on a plurilaterial basis.

For PAs to become a functional and feasible approach for advancing deeper regulatory cooperation at the WTO, Article X:9 of the WTO Agreement must be amended to no longer require approval of PAs by the full membership. In order secure the necessary support for that amendment, WTO members should also agree to a binding principles limiting the use of PAs. These principles should include assurances that non-signatories will not be compelled to adopt PAs at a later date. The principles should also provide that Members may join these agreements later with the same conditions that applied to the original signatories and require implementation support to be provided for least developed member countries (Lawrence, 2006). Requiring the creation of an observer status for nonparticipating WTO members would also ensure the non-participating WTO members have full transparency and can raise concerns.

The choice of topic for PAs should be member-state driven and reflect the need for interested governments to advance shared social preferences and efficient and effective regulatory oversight as part of global economic integration. This is most likely to occur in sectors that depend on internationally consistent, adequate, and efficient rules and standards for both freer trade and more effective regulatory oversight. These include goods and services sectors dominated by GVCs, such as automobiles, chemicals, and consumer goods (Bollyky, 2015). A particularly promising area is digital trade in goods and services, where regulatory paradigms in some countries are less entrenched and the adequacy and efficiency of global regulatory oversight in privacy, security, consumer protection, contract enforcement depends on international cooperation and consistency (Manyika et al., 2015; Metzler, 2015).

The design of PAs should, of course, depend on the sector and the objectives for trade and regulatory cooperation. The WTO General Agreement on Trade Services (GATS) provides a potentially useful model for a rolling process of rule-making in a still novel area. The contribution of the GATS was to expand the coverage of services in the multilateral trading system but to do so in a way that afforded flexibility to countries undertaking new commitments.

In the regulatory cooperation context, this approach might involve a baseline set of rules and a venue for engagement on regulatory transparency, information sharing, and explanations of new rules. The agreement should establish priorities and transparent procedures but otherwise be left broad, allowing member countries the flexibility to collaborate on emerging challenges. It might operate in a hub-and-spoke model and include voluntary, topic-specific, regulator-led working groups for interested members to negotiate deeper forms of regulatory cooperation. (Stewart, 2016) The hub, perhaps a Committee of participating member states with observer member states present, should: prepare common technical regulations and standards; recommend adoption of international standards; and promote the sharing of surveillance data and inspection reports through the development of confidentiality arrangements. The substance of these recommendations and proposals should be generated through the ad hoc, regulator-led working groups. These groups should be open to consultation with non-state actors and experts. The recommendations and proposals of the Committee should be made public and subject to notice and comment. ${ }^{64}$

Maintaining the sovereignty and local accountability of national regulatory authorities will be essential to the success. Agreed upon regulatory cooperation measures should not have binding domestic legal effect. Thereby, where new legislation is required to implement such measures,

64 Bollyky (2012) makes similar recommendations with regard to what would have been a ' $21^{\text {st }}$ century approach' to regulatory coherence in the TPP. 
opportunity for parliamentary scrutiny is assured. Participating member states should, however, commit to decide on whether to adopt these joint recommendations within a fixed period of time and to provide a written, detailed explanation when deciding not to do so. Given the novelty of the regulatory coherence chapter and sensitivities around regulatory independence, subjecting the agreement to WTO dispute resolution would likely only discourage participation and inclusion of strong provisions in this area.

\subsubsection{Expanding Partnerships}

The state-to-state nature of WTO operations is increasingly outdated. Even a brief perusal of PTAs suffices for the reader to understand that a lot more is requested from business and civil society in this context. Public-private partnerships are now common in investment projects and in GVCs. The WTO needs to play a larger role in working with partners to create the broadly-supported governance frameworks that can advance international regulatory cooperation in the areas that most affect trade and investment (Hoekman, 2015).

Regulatory cooperation is not the exclusive mandate of the WTO. Many other institutions, including the OECD, Food and Agriculture Organization of the United Nations, World Economic Forum, World Health Organization, and the International Centre for Trade and Sustainable Development, are in this space and can take the lead in setting substantive norms. The World Bank, regional development banks, and donors such as the Bill and Melinda Gates Foundation are all supporting regulatory cooperation initiatives and might offer financial resources for capacity-building, policy dialogue, and monitoring here too.

Greater engagement of the WTO with business organizations and civil society is particularly important. Firms participate in and manage GVCs, engage in private and nongovernmental international standard setting initiatives, and support corporate social responsibility and capacity building programs. Civil society, nongovernmental institutions, and academic institutions have expertise and the deep understanding of local circumstances to contribute agenda setting and ongoing problem solving.

\subsubsection{Multilateralizing Progress in PTAs}

The WTO needs a mechanism to 'multilateralize' the important regulatory cooperation that will inevitably happen in smaller clubs of like-minded countries, such as PTAs or regional economic communities. ${ }^{65}$ Multilateralizing that progress would reduce business costs, expand regulatory cooperation and the fulfillment of shared social preferences, and unlock the welfare benefits of trade liberalization in both the WTO and the PTAs. ${ }^{66}$

One idea could be to initiate automatic negotiations any time a fixed number of countries belonging to the three distinct WTO groups (developed; developing; and least developed countries) entered into comparable arrangements on regulatory cooperation in separate agreements. Another idea would be to tie those automatic negotiations to the adoption of regulatory cooperation in a PTA covering a high percentage (such as eighty-five percent or more) of global trade in a goods or services sector.

65 Low \& Baldwin (2009); Trachtman (2007) make similar suggestions.

66 Baldwin (2015) notes that EU has a similar 'clubs within the club' approach with its Closer Cooperations, or Enhanced Cooperations. Wolfe (2011) has expressed a similar view regarding the role of OECD, an institution that shapes but, unlike the WTO, does not codify trade law. PTAs codify trade law of course, but may be also able to shape the multilateral process as well. 


\section{Conclusion}

Can the WTO evolve? The institution remains a product of the post-World War II, Bretton Woods era, created by a coalition of powerful states, and vested with their authority to act as their agent in addressing well-defined coordination and governance problems emerging from their interdependence. Like many of its sister institutions from this era, such as the World Bank, the International Monetary Fund, the United Nations and its agencies such as the World Health Organization, the WTO has struggled as power dispersed to a greater number of states and non-state interests and broad-based consensus became harder to reach. It is no answer to state that the WTO will evolve because it must to survive. This has been true for many post-World War II era intergovernmental institutions for decades. Many have not and may never evolve.

The emergence of GVCs, however, provides the WTO with an opportunity. In the sectors where this production model dominates, GVCs create a potential alignment of the interests of a wide diversity of states and non-state actors interested in freer trade, better regulation, and broader economic development. PTAs, standard setting organizations, and regulator-to-regulator initiatives are making important progress in advancing the international regulatory cooperation needed in the GVC era. That progress is limited, however, because these arrangements do not encompass the full range of countries in global commerce.

This paper advocates changes in the corporate governance of the GATT/WTO to reflect the decline in tariffs and border restraints to commerce and the emerging challenges of advancing trade, regulation cooperation, and social preferences in a global economy dominated by GVCs. Together, these changes form a positive integration strategy that we refer to as the new WTO Think. This strategy remains rooted in the original rationale of the GATT (or GATT-think) of reducing the negative externalities of unilateral action and solving important international coordination challenges, but is more inclusive of regulators and non-state actors and more flexible and positive in its means. In particular, the WTO should embrace the confluence of shared social preferences and trade, where it exists, as a motivation for advancing international regulatory cooperation. It should multilateralize the important regulatory cooperation occurring in smaller clubs of like-minded countries and adopt changes to facilitate the use of PAs where agreement across all WTO members is not yet possible.

While making these corporate governance changes will not be easy, they are feasible. There are precedents to draw upon from the Tokyo Round codes. The GATS and, more recently, the EGA negotiations offer potential lessons for other tackling other regulatory cooperation changes at the WTO.

GVCs provide an opportunity for the WTO to evolve, but it is time-limited. As GVCs become less inclusive and more regional in nature, reaching consensus among the relevant actors will only become harder. The time to act is now. 


\section{References}

Antràs, Pol, and Robert W. Staiger. 2012. Offshoring and the Role of Trade Agreements. American Economic Review 102(7):3140-3183.

Bagwell, Kyle, Gene M. Grossman, Henrik Horn, Petros C. Mavroidis, Robert W. Staiger, and Alan O. Sykes. 2013. The Genesis of the GATT Summary, Legal and Economic Principles of World Trade Law. Cambridge: Cambridge University Press.

Bagwell, Kyle, \& Robert W. Staiger. 2002. Economic Theory and the Interpretation of GATT/WTO. The American Economist 46(2):3-19.

Baldwin, Robert E. 1971. Determinants of the Commodity Structure of US Trade. American Economic Review 61(1):126-146.

Baldwin, Richard, 2010. Unilateral Tariff Liberalization, NBER Working Paper No. 16600.

Baldwin, Richard, 2012. Global Supply Chains: Why They Emerged, Why They Matter, And Where They Are Going, CTEI Working Paper 2012-13, Geneva: Centre for Trade and Economic Integration.

Bhagwati, Jagdish and Robert E. Hudec. 1990. Aggressive Unilateralism: America's 301 Trade Policy and the World Trading System. Ann Arbor: University of Michigan Press.

Bollyky, Thomas J. 2009. Global Health Interventions for Food and Drug Safety. Washington, DC: Center for Strategic and International Studies.

Bollyky, Thomas J. 2012. Regulatory coherence in the TPP talks, pp. 171-186 in C.L. Lim, Deborah K. Elms, and Patrick Low, eds., The Trans-Pacific Partnership: A Quest for a Twenty-First Century Trade Agreement. Cambridge: Cambridge University Press.

Bollyky, Thomas J. 2012. Better Regulation for Freer Trade, Policy Innovation Memorandum No. 22. Washington, DC: Council on Foreign Relations.

Bollyky, Thomas J. 2015. A Role for the WTO on Regulatory Coherence. The E15 Initiative. Geneva: International Centre for Trade and Sustainable Development (ICTSD) and World Economic Forum.

Bown Chad P., and Douglas A. Irwin. 2016. The GATT's Starting Point: Tariff Levels circa 1947, in Manfred Elsig, Bernard Hoekman, and Joost Pauwelyn, (eds.), Assessing the World Trade Organization: Fit for Purpose? Cambridge University Press: Cambridge, UK.

Coglianese, Cary. 2016. Measuring Regulatory Excellence, pp. XXX-XXX in Cary Coglianese, ed., Achieving Regulatory Excellence. Washington, DC: Brookings Institution Press.

De Búrca, Gráinne, Robert O. Keohane, and Charles Sabel. 2014. Global Experimentalist Governance. British Journal of Political Science 44:477-486.

Doyle, Don H. 2015. The Cause of All Nations, Basic Books: Philadelphia, Pennsylvania

Drezner, Daniel W. 2008. All Politics is Global: Explaining International Regulatory Regimes. Princeton: Princeton University Press.

Elliott, Kimberly A. 2012. Labor standards and the TPP, pp. 200-210 in C.L. Lim, Deborah K. Elms, and Patrick Low, eds., The Trans-Pacific Partnership: A Quest for a Twenty-First Century Trade Agreement. Cambridge: Cambridge University Press.

Friedman, Benjamin. 2005. The Moral Consequences of Economic Growth. New York: Knopf.

Gereffi, Gary. 2014. A Global Value Chain Perspective on Industrial Policy and Development in Emerging Markets. Mimeo. 
Greenhill, Brian, Layna Mosely, and Aseem Prakash. 2009. Trade-based Diffusion of Labor Rights: A Panel Study, 1986-2002. American Political Science Review103:669-690.

Helmer, Jesse, and Robert Wolfe. 2007. Trade Policy Begins at Home, pp. 1-21 in Mark Halle and Robert Wolfe (eds.), Process Matters, Sustainable Development and Domestic Trade Transparency, IISD: Winnipeg, Manitoba.

Hoekman, Bernard M. 2014. Supply Chains, Mega-Regionals and Multilateralism: A Road Map for the WTO. EUI-RSCAS Working Paper2014/27. http://cadmus.eui.eu/bitstream/handle/1814/30198/RSCAS_2014_27_Rev2.pdf

Hoekman, Bernard M. 2015. Fostering Transatlantic Regulatory Cooperation and Gradual Multilateralization. Journal of International Economic Law, 18, 609-624.

Hoekman, Bernard M. 2016. "Behind the Border" Policies: Regulatory Cooperation and Trade Agreements, pp. 69-96 in Bernard Hoekman and Carlos A. Primo Braga (eds.), Future of the Global Trade Order, European University Institute \& IMD: Lausanne, Switzerland.

Hoekman, Bernard M., and Petros C. Mavroidis. 2015. World Trade Organization (WTO): Law, Economics, and Politics, 2nd ed. New York: Routledge.

Horn, Henrik, Giovanni Maggi, and Robert W. Staiger. (2010). Trade Agreements as Endogenously Incomplete Contracts. American Economic Review 100:394-419.

Horn, Henrik, Petros C. Mavroidis, and André Sapir. 2010. Beyond the WTO? An Anatomy of the US and EU Preferential Trade Agreements, The World Economy, 33: 1565-1588.

Howse, Robert. 2015. Regulatory Cooperation, Regional Trade Agreements, and World Trade Law: Conflict or Complementarity? Law and Contemporary Problems 78:137-151.

Jacobs, S. and Ladegaard, P. 2010. Regulatory Governance in Developing Countries, Washington DC: International Finance Corporation.

Johnson, Harry, G. 1953-4. Optimum Tariffs and Retaliation, Review of Economic Studies, 1: 142-53.

Immelt, Jeffrey 2016. The World I See. Text of Commencement Address to New York University Stern School of Business, available at http://fortune.com/2016/05/20/ge-immelt-globalization/.

Inglehart, Robert, 2000. Globalization and Postmodern Values, The Washington Quarterly, 23:1 pp. $215-228$.

Institute of Medicine. 2013. International Regulatory Harmonization Amid Globalization of Drug Development: Workshop Summary. Washington, DC: The National Academies Press.

Irwin, Douglas A. 2015. Free Trade Under Fire. Princeton: Princeton University Press.

Irwin, Douglas A., Petros C. Mavroidis, and Alan O. Sykes. 2007. The Genesis of the GATT. Mimeo.

Jackson, John H. 1969. World Trade and the Law of GATT. Indianapolis: Bobbs-Merrill.

Krugman, Paul R. 1991. The Move Toward Free Trade Zones, pp. 5-24 in Economic Review. Kansas City: Federal Reserve Bank of Kansas City.

Krugman, Paul. 1997. What should trade negotiators negotiate about?. Journal of Economic Literature 35:113-120.

Levi-Faur, David. 2005. The Global Diffusion of Regulatory Capitalism. The Annals of the American Academy of Political and Social Science 598:12-32.

Limão, Nuno. 2016. Preferential Trade Agreements, pp. XXX-XXX in Kyle Bagwell and Robert W. Staiger, eds., Handbook in Commercial Policy. New York: Oxford University Press. 
Maertens, Miet, and Johan F.M. Swinnen. 2009. Trade, Standards, and Poverty: Evidence from Senegal. World Development 34:161-178.

Maskus, Keith et al., 2005. The Cost of Compliance with Product Standards for Firms in Developing Countries: An Econometric Study, World Bank Policy Research Working Paper No. 3590, Washington, D.C.

Maskus, Keith. 2012. Private Rights and Public Problems: The Global Economics of Intellectual Property in the 21st Century. Washington, DC: Petersen Institute of International Economics.

Mavroidis, Petros C. 2016. The Regulation of International Trade: GATT. Cambridge, MA: MIT Press.

Mavroidis, Petros C, and André Sapir. 2015. Dial PTAs for Peace: The Influence of Preferential Trade Agreements on Litigation between Trading Partners, Journal of World Trade, 49: 351-374.

Mavroidis, Petros C., and Robert Wolfe. 2015. From Sunshine to a Common Agent: The Evolving Understanding of Transparency in the WTO. Brown Journal of World Affairs XXI:117-130.

Moravcsik, Andrew. 1997. Taking Preferences Seriously: A Liberal Theory of International Politics. International Organization 51:519.

National Academy of Sciences. 2012. Ensuring Safe Foods and Medical Products Through Stronger Regulatory Systems Abroad. Committee on Strengthening Core Elements of Regulatory Systems in Developing Countries; Board on Global Health; Board on Health Sciences Policy; Institute of Medicine. Washington, DC: National Academies Press.

OECD. 2002. Regulatory Policies in OECD Countries: From Interventionism to Regulatory Governance, Paris: OECD.

OECD. 2005. Guiding Principles of Regulatory Quality and Performance, Paris: OECD.

OECD. 2013. International Regulatory Co-operation: Addressing Global Challenges. Paris: OECD Publishing.

OECD. 2015. Inclusive Global Value Chains: Policy Options in Trade and Complementary Areas for GVC Integration by Small and Medium Enterprises and Low-Income Developing Countries. Paris: OECD Publishing.

Orefice, Gianluca, and Nadia Rocha. 2011. Deep Integration and Production Networks: An Empirical Analysis. World Trade Organization Staff Working Paper ERSD-2011-11.

Pinker, Steven. 2011. The Better Angels of Our Nature, Why Violence Has Declined. New York: Penguin Books.

Porter, Michael E. (1985) "Technology and Competitive Advantage", Journal of Business Strategy, Vol. 5 Iss: 3, pp.60 - 78

Radelet, Steven. 2015. The Great Surge. New York: Simon \& Schuster.

Regan, Donald H. 2006. What Are Trade Agreements For? - Two Conflicting Stories Told by Economists with a Lesson for Lawyers, Journal of International Economic Law 9(4), 951-988.

Roberts, Donna, and Tim Josling. 2011. Tracking the Implementation of Internationally Agreed Standards in Food and Agricultural Production. Washington, DC: International Food \& Agricultural Trade Policy Council.

Sabel, Charles F., and David G. Victor. 2015. Governing Global Problems under Uncertainty: Making Bottom-Up Climate Policy Work, Climatic Change, 136:.1-13.

Shaffer, Gregory. 2015. How the World Trade Organization shapes regulatory governance. Regulation \& Governance 9:1-15. 
Slaughter, Anne Marie. 1992. Regulating the World: Multilateralism, International Law, and the Projection of the New Deal Regulatory State, pp. 125-156 in John Ruggie, ed., Multilateralism Matters: The Theory and Praxis of an Institutional Form. New York: Columbia University Press.

Steger, Debra P. 2012. Institutions for Regulatory Cooperation in 'New Generation' Economic and Trade Agreements. Legal Issues of Economic Integration 39:109-126.

Sykes, Alan O. 1999.'The (limited) role of regulatory harmonization in international goods and service markets," Journal of International Economic Law 2(1) 49-70.

Trachtman, Joel P. 2007. International Trade: Regionalism, pp. 151-176 in Andrew T. Guzman and Alan O. Sykes, eds., Research Handbook in International Economic Law. Northampton, MA: Edward Elgar.

U.S. Food \& Drug Administration. 2012, Global Engagement Report, U.S. Food and Drug Administration: Silver Spring MD, available at http://www.fda.gov/downloads/AboutFDA/ReportsManualsForms/Reports/UCM298578.pdf

Vogel, David. 1995. Trading Up: Consumer and Environmental Regulation in a Global Economy. Cambridge, MA: Harvard University Press.

Wijkström, Erik N. 2015. The Third Pillar: Behind the Scenes, WTO Committee Work Delivers. The E15 Initiative. Geneva: International Centre for Trade and Sustainable Development (ICTSD) and World Economic Forum.

WTO. 2000. TBT Committee Decision on Principles for the Development of International Standards, Guides and Recommendations with Relation to Articles 2, 5 and Annex 3 of the TBT Agreement contained in Annex 2 of G/ TBT/1/Rev. 12.

Wolfe, Robert. 2011. The OECD contribution to the Evolution of $21^{\text {st }}$ Century Trade Law, George Washington International Law Review, 43: 277-293.

World Bank. 2005. Food Safety and Agricultural Health Standards: Challenges and Opportunities for Developing Country Exports, World Bank Report No. 31207. Washington, DC: World Bank.

WTO. 2009. World Trade Report 2009 - Trade Policy Commitments and Contingency Measures. Geneva: World Trade Organization.

WTO. 2011. World Trade Report 2011 - The WTO and preferential trade agreements: From coexistence to coherence. Geneva: World Trade Organization.

WTO. 2014. World Trade Report 2014 - Trade and development: recent trends and the role of the WTO. Geneva: World Trade Organization. 
Author contacts:

\section{Thomas J. Bollyky}

Council on Foreign Relations

1777 F Street NW

Washington, DC20006

Email: tbollyky@cfr.org

\section{Petros C. Mavroidis}

Columbia Law School

435 W. 116th St

New York NY 10027

Email: pmavro@law.columbia.edu 